\title{
IMPLEMENTASI GERAKAN LITERASI SEKOLAH DALAM MENINGKATKAN BUDI PEKERTI SISWA DI SMK NUSANTARA JOMBANG
}

\author{
Desy Naelasari \\ Prodi Pendidikan Agama Islam, STIT al Urwatul Wutsqo Jombang \\ e-mail: naelasaridesy@gmail.com \\ Nazilatul Izza \\ Prodi Pendidikan Agama Islam, STIT al Urwatul Wutsqo Jombang \\ e-mail: nazilatulizza05@gmail.com
}

\begin{abstract}
Literacy is inseparable from the world of education. Literacy is a means for students to recognize, understand, and apply the knowledge they get in school. Literacy is also related to the lives of students, both at home and in the surrounding environment to foster noble character. The results of this study include: 1 . The school literacy movement at SMK Nusantara is at the learning stage, namely the implementation of various strategies to understand texts in all subjects. Which is then supported by the use of physical, social, affective and academic environments accompanied by a variety of readings (print, visual, auditory, digital), which are rich in literacy outside textbooks to enrich knowledge in subjects. 2. The character of class X students in SMK Nusantara is enhanced by practicing morals towards God, towards others and the environment. 3. Implementation of the school literacy movement in improving the character of class X students at SMK Nusantara by: a. Examples or examples taken by the teacher, b. Spontaneous activity, c. Reprimand or punishment given to students who do not take part in literacy activities, d. The coding of the environment by providing a literal environment, e. Routine activities.
\end{abstract}

Keywords: School Literacy Movement, character

\section{PENDAHULUAN}

Pendidikan merupakan salah satu faktor penting dalam meningkatkan sumber daya manusia dan taraf kehidupan bangsa. Seperti tercantum dalam tujuan pendidikan nasional nomor 20 Tahun 2003 pasal 3 yang berbunyi: 'Pendidikan Nasional berfungsi mengembangkan kemampuan dan membentuk watak serta peradaban bangsa yang bermartabat dalam rangka mencerdaskan kehidupan bangsa, bertujuan untuk berkembangnya potensi siswa agar menjadi manusia yang beriman dan bertawa 
terhadap Tuhan yang Maha Esa, berakhlak mulia, sehat, berilmu, cakap, kreatif, mandiri dan menjadi warga negara yang demokratis serta bertanggung jawab". ${ }^{1}$ Dalam menunjang hal tersebut harus diterapkan sstem literasi disetiap lembaga.

Literasi tidak terpisahkan dari dunia pendidikan. Literasi menjadi sarana peserta didik dalam mengenal, memahami, dan menerapkan ilmu yang didapatkannya di bangku sekolah. Literasi juga terkait dengan kehidupan peserta didik, baik di rumah maupun di lingkungan sekitarnya untuk menumbuhkan budi pekerti mulia. Literasi, di awal, dimaknai 'keberaksaraan' dan selanjutnya dimaknai 'melek' atau 'keterpahaman'. Pada langkah awal, 'melek baca' dan 'tuli s' ditekankan karena kedua keterampilan berbahasa ini merupakan dasar bagi pengembangan melek dalam berbagai hal atau disebut "multiliterasi"

Begitu pentingnya membaca hingga ketahui bahwa surat pertama yang turun pada Al-Qur'an adalah surat Al-'Alaq, yang pada kata pertamanya adalah kata Iqro' yang mempunyai arti bacalah. Pada surat ini juga mengandung hikmah rahmat Allah yang mengajarkan kepada manusia segala apa yang belum diketahui dengan membaca.

Pernyataan tentang membaca adalah jendela dunia memang tidaklah salah, karena membaca merupakan hal yang penting dalam rangka mendapatkan informasi baru yang belum kita ketahui. Hal tersebut terbukti pada saat ini di galakkan dengan gerakan literasi sekolah. Gerakan literasi sekolah adalah Gerakan yang telah dicanangkan sejak akhir tahun 2014. ${ }^{3}$ menjelaskan berbagai upaya dilakukan untuk menggerakkan ekosistem sekolah dalam melakukan kegiatan berliterasi dan mengembangkan sikap. Upaya sistematis dan berkesinambungan perlu dilakukan untuk meningkatkan kemampuan literasi siswa. Saat ini, program gerakan literasi sekolah (GLS) untuk menumbuhkan minat baca dan kecakapan literasi telah dicanangkan disebagian sekolah dalam berbagai kegiatan, antara lain 15 menit membaca sebelum pembelajaran, sebagaimana diamanatkan oleh Permendikbud Nomor 23 Tahun 2015.

Kondisi minat baca di Indonesia cukup memprihatinkan, berdasarkan studi yang dilakukan Most Littered National In The World yang di lakukan pada bulan Maret tahun

1 Ainamulyana. bttps:// ainamulyana.blogspot,com/2018/06/undang-undang-uu-nomor-20-tabun-2003.btml?m1. 2 Agustus 2018.

2 D. P. Kemendikbud, Materi Pelatihan: Strategi Literasi Dalam Pembelajaran, (2017), 6.

${ }^{3}$ D. P. Kemendikbud, Materi Pelatihan: Strategi Literasi Dalam Pembelajaran, (2017), 6. 
2017 negara Indonesia menempati peringkat ke-60 dari 61 negara soal minat membaca. Indonesia tepat berada di bawah Thailand (59) dan di atas Bostwana (61). Padahal, dari segi penilaian infrastruktur untuk mendukung minat membaca peringkat Indonesia berada di atas negara - negara Eropa, Indonesia berada diurutan 34 di atas Jerman, Portugal, Selandia Baru dan Korea Selatan. Jadi dapat diartikan bahwa minat baca warga negara Indonesia yang rendah bukan dari segi infrastruktur tetapi dari kesadaran warga negara Indonesia tentang bagaimana pentingnya minat baca yang befungsi untuk meningkatkan pengetahuan kita terhadap berbagai informasi baru.

Inilah fenomena yang terjadi diera digital ini, keberadaan buku bukan menjadi sesuatu hal yang menarik lagi keberadaannya telah tergeserkan dan terlupakan oleh game online, gadget, dan permainan modern lainnya. Melihat hal tersebut maka bukan hanya merenung saja akan tetapi perlu adanya tindakan yang nyata dari berbagai pihak untuk menjadikan buku sebagai sesuatu yang berarti yaitu buku sebagai sumber ilmu.

Banyak sekolah yang menerapkan gerakan literasi, gerakan tersebut tidak lain bertujuan untuk membentuk budi pekerti siswa terhadap pentingnya perilaku membaca dan menambah wawasan pengetahuan baru. Gerakan literasi ini juga di laksanakan di SMK Nusantara Diwek Jombang, gerakan literasi ini bertujuan untuk membentuk budi pekerti siswa terhadap pentingnya minat membaca buku untuk menambah pengetahuan baru.

Gerakan literasi yang di laksanakan bertujuan untuk menambah minat baca siswa di SMK Nusantara Diwek Jombang. Karena pada dasarnya minat baca siswa SMK Nusantara bisa dikatakan sangat rendah, menurut. sebagai kepala perpustakaan, dalam satu minggu hanya beberapa siswa saja yang mau datang ke perpustakaan untuk membaca. Namun setelah adanya gerakan literasi sekolah atau biasa disingkat dengan GLS ini, minat membaca siswa meningkat. Walaupun siswa tidak datang ke perpustakaan, tetapi sudah disediakan sudut baca di kelas yang berisi buku-buku bacaan, diharapkan dengan gerakan literasi ini dapat meningkatkan budi pekerti siswa terhadap minat baca. Berdasarkan latar belakang yang telah diuraikan di atas, peneliti tertarik untuk melakukan penelitian tentang bagaimana implementasi gerakan literasi sekolah dalam meningkatkan budi pekerti siwa kelas x yang berada di SMK Nusantara Diwek Jombang. 


\section{PEMBAHASAN}

\section{A. Gerakan Literasi Sekolah}

1. Pengertian Literasi

Literasi berasal dari bahasa Latin litteratus (littera) yang setara dengan kata letter dalam bahasa Inggris yang merujuk pada makna kemampuan membaca dan menulis. Di Indonesia, pada awalnya literasi dimaknai 'keberaksaraan' dan selanjutnya dimaknai 'melek' atau 'keterpahaman'. Pada langkah awal, “melek baca dan tulis" ditekankan karena kedua keterampilan berbahasa ini merupakan dasar bagi pengembangan melek dalam berbagai hal. Pemahaman literasi pada akhirnya tidak hanya merambah pada masalah baca tulis saja, bahkan sampai pada tahap multiliterasi. Dalam Undang-Undang No 3 Tahun 2017 tentang Sistem Perbukuan literasi dimaknai sebagai "kemampuan untuk memaknai informasi secara kritis sehingga setiap orang dapat mengakses ilmu pengetahuan dan teknologi sebagai upaya dalam meningkatkan kualitas hidupnya". 4

Pengertian literasi dalam panduan gerakan literasi sekolah menengah kejuruan adalah kemampuan mengakses, memahami dan menggunakan sesuatu secara cerdas melalui berbagai aktivitas yang siswa lakukan, baik membaca, melihat, menyimak, menulis dan atau berbicara.

Gerakan literasi yang dimaksud dalam skripsi ini adalah kegiatan yang dilakukan untuk mengasah kemampuan siswa dalam mengakses, memahami dan menggunakan sesuatu secara cerdas melalui suatu kegiatan membaca dan menulis. Literasi dalam lingkup sekolah merupakan kemampuan seorang siswa mengembangkan apa yang siswa peroleh dari membaca dan menulis supaya siswa menjadi lebih kreatif, produktif, berdaya saing, berkarakter dan nasionalis serta menumbuhkan budi pekerti yang baik bagi siswa.

Gerakan literasi sekolah atau yang biasa disingkat dengan GLS merupakan suatu upaya pemerintah untuk menjadikan sekolah sebagai organisasi pembelajaran yang warganya literat sepanjang hayat melalui pelibatan publik. Gerakan literasi sekolah dikembangkan berdasarkan

${ }^{4}$ D. P. Kemendikbud, Materi Pelatihan: Strategi Literasi Dalam Pembelajaran, (2017), 7. 
Peraturan Menteri Pendidikan dan Kebudayaan No 23 tahun 2015 yaitu tentang penumbuhan budi pekerti dengan membiasakan siswa membaca buku non pelajaran sebelum waktu belajar dimulai. Hal ini dilakukan untuk menumbuhkan minat membaca siswa, dan membiasakan siswa dengan buku serta memperbaiki kemampuan siswa dalam membaca agar menjadikan siswa yang berbudi pekerti luhur. ${ }^{5} \mathrm{Pada}$ dasarnya terdapat tiga tahapan pelaksanaan Gerakan Literasi Sekolah, dimulai dari Tahap Pembiasaan, Tahap Pengembangan, sampai pada tahap Pembelajaran. ${ }^{6}$

a. Tahap pembiasaan: penumbuhan minat baca melalui kegiatan 15 menit membaca, tanpa tagihan.

b. Tahap pengembangan: meningkatkan kemampuan literasi melalui kegiatan menanggapi buku pengayaan; ada tagihan non akademik.

c. Tahap pembelajaran: meningkatkan kemampuan literasi disemua pelajaran: menggunakan buku pengayaan dan strategi membaca disemua mata pelajaran; ada tagihan akademik dan/atau non akademik.

Kementerian pendidikan dan kebudayaan.${ }^{7}$ dalam menjelaskan fokus kegiatan dalam tahap literasi sekolah sebagai berikut:

Tabel fokus kegiatan dalam tahap literasi sekolah

\begin{tabular}{|c|c|}
\hline Tahapan & Kegiatan \\
\hline $\begin{array}{l}\text { Pembiasaan } \\
\text { (belum ada } \\
\text { tagihan) }\end{array}$ & $\begin{array}{l}\text { 1. Lima belas menit membaca setiap hari sebelum jam } \\
\text { pelajaran, melalui kegiatan membacakan buku dengan } \\
\text { nyaring (read alond) atau seluruh warga sekolah } \\
\text { membaca dalam hati (sustained silent reading). } \\
\text { 2. Pembangunan lingkungan fisik sekolah yang kaya } \\
\text { literasi antara lain (a) penyediaan perpustakaan } \\
\text { sekolah, sudut baca, dan area baca yang nyaman, (b) } \\
\text { pengembangan sarana lain (UKS, kantin, kebun } \\
\text { sekolah), dan (c) penyediaan koleksi teks cetak, visual, }\end{array}$ \\
\hline
\end{tabular}

5 Ibid 3

${ }^{6}$ D. P. Kemendikbud, Materi Pelatihan: strategi Literasi Dalam Pembelajaran. (2017). 8

${ }^{7}$ H. Yunansah, \& T., Mulyani, Y., Abidin, Pembelajaan Literasi Strategi Meningkatkan Kemampuan Literasi Matematika, Sains, Membaca, dan Menulis. . (Jakarta: Bumi Aksara, 2018) 4. 


\begin{tabular}{|c|c|c|}
\hline & & $\begin{array}{l}\text { digital, maupun multimodal yang mudah diakses oeh } \\
\text { warga sekolah, (d) pembuatan bahan kaya teks (print- } \\
\text { rich materials). }\end{array}$ \\
\hline $\begin{array}{l}\text { Pengembangan } \\
\text { (ada tagihan } \\
\text { sederhana } \\
\text { untuk penilaian } \\
\text { non akademik) }\end{array}$ & 1. & $\begin{array}{l}\text { Lima belas menit membaca setiap hari sebelum jam } \\
\text { pelajaran, melalui kegiatan membacakan buku dengan } \\
\text { nyaring, membaca dalam hati, membaca bersama, } \\
\text { dan/atau membaca terpandu diikuti kegiatan lain } \\
\text { dengan tagihan non-akademik, contoh: membuat peta } \\
\text { cerita (story map), menggunakan graphic organizers, dan } \\
\text { bincang buku. } \\
\text { Pengembangan lingkungan fisik, sosial, dan afektif } \\
\text { sekolah yang kaya literasi, serta menciptakan ekosistem } \\
\text { sekolah yang menghargai keterbukaan dan kegemaran } \\
\text { terhadap pengetahuan dengan berbagai kegiatan antara } \\
\text { lain: (a) memberikan penghargaan kepada capaian } \\
\text { perilaku positif, kepedulian sosial, dan semangat } \\
\text { belajar peserta didik. Penghargan ini dapat dilakukan } \\
\text { pada setiap upacara bendera hari Senin dan/atau } \\
\text { perigatan lain, (b) kegiatan akademik lain yang } \\
\text { mendukung terciptanya budaya literasi di sekolah } \\
\text { (belajar di kebun sekolah, belajar di lingkungan luar } \\
\text { sekolah, wisata perpustakaan kota/ daerah dan taman } \\
\text { bacaan masyarakat, dll). } \\
\text { Pengembangan kemampuan literasi mealui kegiatan di } \\
\text { perpustakaan sekolah, perpustakaan kota/ daerah } \\
\text { taman bacaan masyarakat, atau sudut baca kelas } \\
\text { dengan berbagai kegiatan antara lain (a) membacakan } \\
\text { buku dengan nyaring, membaca dalam hati membaca } \\
\text { bersama (shared reading), membaca terpadu (guided } \\
\text { reading), menonton film pendek, dan/atau membaca } \\
\text { teks visual atau digital (materi dari internet), (b) peserta }\end{array}$ \\
\hline
\end{tabular}




\begin{tabular}{|l|l|}
\hline didik merespon teks (cetak/visual/dgital), iksi dan non \\
fiksi, melalui beberapa kegiatan sederhana, seperti \\
menggambar, membuat peta konsep, derdiskusi dan \\
berbincang tentang buku.
\end{tabular}

2.Budi Pekerti

a. Pengertian Budi Pekerti

Kata budi pekerti adalah tingkah laku, perangai, akhlak. ${ }^{8}$ Dalam bahasa Sansekerta budi pekerti berarti tingkah laku, atau perbuatan yang sesuai dengan akal sehat. Yaitu perbuatan yang sesuai dengan nilai-nilai, moralitas masyarakat yang terbentuk sebagai adat istiada. ${ }^{9}$ Pengertian budi pekerti mengacu pada pengertian dalam bahasa Inggris, yang diterjemahkan sebagai moralitas. Moralitas mengandung beberapa pengertian antara lain: (a) adat istiadat, (b) sopan santun, (c) perilaku.

budi pekerti berinduk pada etika atau filsafat moral. Secara etimologis kata etika sangat dekat dengan moral. Etika berasal bahasa Yunani ethos(jamak: ta etha) yang berarti adat kebiasaan. ${ }^{10}$ Adapun moral berasal dari bahasa Latin mos (jamak: mores) yang juga mengandung arti adat kebiasan. Jadi pendidikan budi pekerti memiliki makna yang sama dengan pendidikan moral, pendidikan karakter, pendidikan akhlak dan pendidikan nilai.

Sejalan dengan itu menurut Ibrahim yang dikutip oleh Rahmawati, juga berpendapat budi pekerti bukan pikiran, budi pekerti bukan pengetahuan, budi pekerti bukan semata-mata gerak gerik lahir, tetapi budi adalah satu bentuk atau bangunan dalam jiwa yang menggerakkan perbuatan dan tingkah laku yang terpuji dan mulia serta menangkis segala yang tercela

${ }^{8}$ N. Zuriah, Pendidikan Moral \& Budi Pekerti Dalam Perspektif Perubahan, ( Jakarta: Bumi Aksara : 2015), 15.

9 S. Adisusilo, Pembelajaran Nilai Karakter Kontruktivisme dan VCT Sebagai Inovasi Pembelajaran Aktif.( Jakarta: Raja Grafino Persada : 2013), 15.

10 Ibid., 20 
dan hina ${ }^{11}$. Sedangkan menurut Sedyawati mengemukakan pengertian budi pekerti yang paling hakiki adalah perilaku. Adapun sikap dan perilaku budi pekerti ini mengandung lima jangkauan, yaitu sikap prilaku yang berhubungan dengan Tuhan, diri sendiri, keluarga, masyarakat dan bangsa serta lingkungan sekitar.

b. Ruang Lingkup Materi dan Substansi Pendidikan Budi Pekerti

Ruang lingkup pendidikan budi pekerti menurut yang dikutip oleh secara garis besar dapat dikelompokkan dalam tiga hal nilai akhlak yaitu: ${ }^{12}$ akhlak terhadap Tuhan yang Maha Esa, akhlak terhadap sesama manusia dan akhlak terhadap lingkungan

Ruang lingkup atau scope pembahasan nilai budi pekerti yang bersumberkan pada etika atau filsafat moral menekankan unsur utama kepribadian, yaitu kesadaran dan berperannya hati nurani dan kebajikan bagi kehidupan yang baik berdasarkan sistem dan hukum nilai-nilai moral masyarakat. Hati nurani (ada yang menyebutnya kata hati, suara hati dan suara batin) adalah kesadaran untuk mengendalikan atau mengarahkan perilaku seseorang dalam hal yang baik dan menghinari dari tindakan yang buruk. Kebajikan atau kebaikan merupakan watak unggulan yang berguna dan menyenangkan bagi diri sendiri dan orang lain. Dengan demikian, terdapat hubungan antara budi pekerti dengan nlai-nilai moral dan norma hidup yang unsur-unsurnya merupakan ruang lingkup pembahasan budi pekerti.

Budi pekerti adalah nilai-nilai hidup manusia yang sungguh-sunguh dilaksanakan bukan karena sekedar kebiasaan, tetapi berdasarkan pemahaman dan kesadaran diri untuk menjadi baik. Nilai-nilai yang disadari

${ }^{11}$ Rahmawati, Y. Musik Sebagai Pembentuk Budi Pekerti Sebuah Panduan Untuk Pendidikan. (Yogyakarta: Panduan. 2005), 5

${ }^{12}$ S. Adisusilo, Pembelajaran Nilai Karakter Kontruktivisme dan VCT Sebagai Inovasi Pembelajaran Aktif.( Jakarta: Raja Grafino Persada: 2013), 25 
dan dilaksanakan sebagai budi pekerti hanya dapat diperoleh melalui proses yang berjalan sepanjang hidup manusia. ${ }^{13}$

\section{ANALISIS}

\section{A. Gerakan Literasi Sekolah di SMK Nusantara}

Gerakan Literasi sekolah di SMK Nusantara telah sampai pada tahap pembelajaran. Karena pada prinsipnya kegiatan gerakan literasi sekolah pada tahap pembiasaan sama dengan tahap pengembangan. Pada tahap pengembangan peserta didik didorong untuk menunjukkan keterlibatan pikiran dan emosinya dengan membaca melalui kegiatan produktif baik lisan maupun tulisan. Dan perlu difahami bahwa kegiatan produktif tersebut tidak dinilai secara akademik. Karena kegiatan tindak lanjut memerlukan waktu tambahan diluar lima belas menit membaca, maka sekolah di dorong untuk memasukkan waktu gerakan literasi sekolah dalam jadwal pelajaran sebagai kegiatan mandiri. Bentuk, frekuensi dan durasi pelaksanaan tindak lanjut dilaksanakan berdasarkan kondisi sekolah. Hal ini dibuktikan dengan pernyataan salah satu guru bahwa kegiatan literasi berjalan selama enam hari, empat hari untuk membaca dan dua hari untuk merangkum buku yang dibaca. Maka hal tersebut menunjukkan adanya keterlibatan fikiran dan emosional

Adapun dari awal kegiatan gerakan literasi sekolah di SMK Nusantara yang telah dijelaskan oleh beberapa guru dengan yang penulis amati ada sedikit perbedaan. Penulis menemukan beberapa hal yang perlu dan penting untuk ditambahkan, yaitu sebelum kegiatan literasi dimulai semua siswa dan guru menyanyikan lagu Indonesia raya dengan hikmat dan dilanjutkan dengan membaca doa. Jadi dalam praktiknya kegiatan gerakan literasi sekolah yang ada di SMK Nusantara dibarengi dengan menyanyikan lagu Indonesia raya seperti yang ditemukan oleh peneliti.

Tahap pembelajaran kegiatan literasi di SMK Nusantara seperti yang penulis amati yaitu setelah lima belas menit membaca buku dengan nyaring, dalam

${ }^{13}$ N. Zuriah, Pendidikan Moral \& Budi Pekerti Dalam Perspektif Perubahan,( Jakarta: Bumi Aksara : 2015), 15. 
hati ataupun bersama maka selanjutnya diikuti tagihan non-pelajaran siswa menganalisis atau menceritakan kembali buku yang telah mereka baca dengan cara story map atau diskusi buku, hal ini dibuktikan dengan adanya berbagai strategi untuk memahami teks dalam semua mata pelajaran. Yang kemudian didukung dengan penggunaan lingkungan fisik, dengan menggunakan media cetak, audio maupun audio visual dan adanya tagihan akademik pada setiap pelajaran. Hal ini sesuai dengan panduan gerakan literasi sekolah di sekolah menengah kejuruan

\section{B. Faktor Pendukung dan Penghambat Gerakan Literasi Sekolah Di SMK Nusantara}

Faktor yang mendukung jalannya kegiatan gerakan literasi sekolah di SMK Nusantara yaitu berupa pengembangan lingkungan fisik, sosial, dan afektif sekolah yang kaya literasi, serta menciptakan ekosistem sekolah yang menghargai keterbukaan dan kegemaran terhadap pengetahuan dengan berbagai kegiatan, yaitu memberikan penghargaan kepada capaian perilaku positif, kepedulian sosial, dan semangat belajar peserta didik. Penghargan ini dapat dilakukan pada setiap upacara bendera hari Senin dan atau perigatan lain.

Berikut adalah sarana dan prasarana yang disediakan oleh sekolah, yaitu meliputi: disediakannya buku bacaan yang memadai jumlahnya, rak buku atau sudut baca pada setiap kelas, mading untuk meletakkan hasil karya siswa, dan perpustakaan sekolah

Sedangkan faktor penghambat gerakan literasi sekolah di SMK Nusantara dalah sebagai berikut: seringnya buku sekolah yang hilang, adanya kegiatan dadakan pada jam literasi sehingga literasi tidak bisa dilaksanakan, dan keadaan siswa yang terkadang gaduh sehingga kegiatan literasi tidak bisa berjalan dengan kondusif

Adapun lingkungan di SMK Nusantara diciptakan agar semua warga memiliki jiwa literat (suka membaca) dengan: membuat sudut baca pada setiap kelas, menyediakan buku fiksi dan non fiksi dalam jumlah yang banyak dan memajang hasil karya siswa. 


\section{Budi Pekerti Siswa Kelas X SMK Nusantara}

Kegiatan yang dilakukan dalam meningkatkan budi pekerti siswa kelas x di SMK Nusantara dengan adanya pembiasaan-pembiasaan berikut:

1. Terhadap Tuhan yang maha esa dengan melaksanakan sholat dhuha dan dzuhur berjamaah

2. Terhadap sesama, dengan bersalaman setiap bertemu dengan guru dan gotong royong dalam setiap kegiatan, misalnya pada saat pemilihan ketua OSIS

3. Terhadap lingkungan sekitar dengan melakukan kerja bakti, bakti sosial dan kegiatan melestarikan lingkungan dengan program satu anak menanam satu pohon

Dari beberapa pembiasaan-pembiasaan diatas sesuai dengan Milan Rianto, ${ }^{14}$ yang dikutip oleh Nurul Zuriah, secara garis besar ruang lingkup pendidikan budi pekerti dapat dikelompokkan dalam tiga hal nilai akhlak yaitu sebagai berikut ${ }^{15}$ :

1. Akhlak Terhadap Tuhan yang Maha Esa

Kita harus percaya kepada tuhan yang menciptakan alam semesta ini, artinya kita wajib mengakui dan meyakini bahwa Tuhan Yang Maha Esa itu memang ada. Kita harus beriman dan bertaqwa kepada-Nya dengan yakin dan patuh serta taat dalam menjalankan segalaperintah-Nya dan menjauhi segala larangan-Nya. Semua agama mempunyai pengertian tentang ketakwaan, secara umum takwa berarti taat melaksanakan perintah-Nya dan menjauhi segala larangan-Nya. Sehingga kita harus ingat dan waspada serta hati-hati jangan sampai melanggar perintah-Nya.

Tuhan Yang Maha Esa adalah maha pemberi, pengasih, dan penyayang. Dalam ajaran agama disebutkan "Mintalah kepada-Ku, Niscaya Aku akan memberinya". Oleh karena itu, janganlah kita merasa bosan untuk berdoa dan memohon, jangan pula cepat menyerah.

Menurut norma agama, jika kita melanggar perintah Tuhan, maka kita akan mendapat hukuman dari Tuhan karena kita berdosa. Manusia

14 Rianto, M. Budi Pekerti dalam PPKn Kini dn Masa Depan. (Malang: tt, 2001),1

15 Zuriah, N, Pendidikan Moral \& Budi Pekerti Dalam Perspektif Perubahan. (Jakarta: Bumi Aksara. 2015), 27-30. 
diciptakan Tuhan mempunyai kewajiban terhadap sang pencipta dan kewajiban terhadap sesama manusia. Setiap perbuatan yang dilakukan atas perintah-Nya disebut ibadah. Banyak perbuatan baik yang merupakan ibadah yang bersifat umumyang diajarkan oleh agama yang ada di dunia ini, seperti tolong menolong dalam kebaikan, kasih sayang, bersikap ramah dan sopan, bekerja keras dalam mencari nafkah, dan tolong menolong dalam kebaikan. Ibadah yang bersifat khusus adalah ibadah yang pelaksanaannya mempunyai tata cara tertentu. Dalam ajaran Islam ajaran yang bersifat khusus antara lain : shalat, puasa, zakat, haji.

\section{Akhlak Terhadap Sesama Manusia}

Manusia harus berbuat baik setiap hari dimana saja. Manusia juga harus berkarya demi kunaan dirinya sendiri, keluarga dan masyarakat bahkan bangsa dan negara. Jika manusia mempunyai banyak kekurangan, maka harus memulai memperbaiki kekurangan, berbuat yang terbaik untuk diri sendiri, masyarakat, bangsa dan negara, serta agama.

Orang tua adalah pribadi yang ditugasi Tuhan untuk melahirkan, membesarkan, memelihara, dan mendidik. Maka sudah sepatutnya seurang anak menghormati dan mencintai orang tua serta taat dan patuh kepadanya.

Akhlak terhadap orang yang lebih tua yaitu menghormati, menghargai, dan mintalah saran, petunjuk, dan bimbingan. Karena orang yang lebih tua lebih banyak pengetahuan, pengalaman dan kemampuannya.

Melakukan tata krama terhadap sesama memang sulit, karena marupakan teman sederajat dan sehari hari berjumpa sehingga lupa memperlakukan dengan tata cara dan sopan yang santun baik. Ketika bergaul dengan teman sebaya harusnya tanpa memandang asal-usul keturunan, suku bangsa, agama maupun status sosial.

Sebagai orang yang lebih tua seharusnya melindungi, menjaga dan membimbing yang lebih muda. 
3. Akhlak Terhadap lingkungan

Manusia tidak mungkin hidup tanpa adanya dukungan lingkungan alam yang sesuai, serasi seperti yang dibutuhkan. Dalam hal ini yang menjadi pendukung hidupnya manusia merupakan flora dan fauna. Flora dan fauna adalah ciptaan Tuhan, oleh karena itu wajib kita lestarikan.

Manusia sebagai makhluk sosial tidak akan pernah bisa hidup tanpa bantuan orang lain. Hubungan antara manusia dengan manusia dalam masyarakat ataupun kelompok harus selaras, serasi dan seimbang.

\section{Implementasi Gerakan Literasi Sekolah dalam Meningkatkan Budi Pekerti Siswa Kelas X}

Implementasi gerakan literasi sekolah dalam meningkatkan budi pekerti siswa kelas x di SMK Nusantara meliputi:

1. Diputarnya murrotal al-Qur'ān setiap pagi hari melalui speker sekolah sampai jam masuk kelas

2. Membaca surat Waqiah setiap selesai sholat dhuha

3. Mengadakan doa bersama dengan membaca istighostah dan tahlil setiap satu bulan sekali

4. Menyanyikan lagu Indonesia raya sebelum memulai kegiatan literasi

5. Memberikan hukuman kepada siswa yan tidak mau mengikuti kegiatan literasi

6. Mengadakan lomba puisi, menulis dan membuat mading dalam peringatan hari besar nasional ataupun hari besar Islam nasional.

Implementasi gerakan literasi sekolah dalam meningkatkankan budi pekerti siswa kelas X dapat diketahui dari:

1. Pemberian contoh dari guru, jadi tidak hanya siswa saja yang membaca saat kegiatan literasi, tetapi guru pun juga ikut membaca serta mengawasi

2. Kegiatan spontan, yaitu dilaksanakannya lomba-lomba yang berkaitan dengan literasi saat hari besar nasional ataupun hari besar Islam

3. Pemberian teguran atau hukuman, bagi siswa yang tidak mau membaca saat kegiatan membaca 15 menit maka akan mendapat hukuman secara langsung. Begitu pula untuk siswa yang melanggar peraturan sekolah maka akan di tegur, bila masih mengulangi kesalahan tersebut hukuman akan diberikan. 
4. Pengkodisian lingkungan yang mendukung terwujudnya warga sekolah yang literat, dibuktikan dengan adanya sudut baca pada setiap kelas, kondisi perpustakaan yang baik, pemajangan hasil karya siswa sebagai motivasi siswa lain.

5. Adanya kegiatan sejenis dengan literasi yang diadakan secara rutin, misalnya saja memutar murrotal Al-Qur'an setiap pagi, membaca surat waqiah setiap selesai sholat dhuha berjamaa dan berdoa sebelum melakukan kegiatan.

Hal tersebut sesuai dengan teori Nurul Zuriah bahwa penerapan pendidikan budi pekerti dilingkungan persekolahan dalam dapat dilakukan pengintegrasian dalam kehidupan sehari-hari melalui cara:

1. Keteladanan atau contoh, misalnya suatu kegiatan yang dilakukan oleh pengawas, kepala sekolah, guru, dan staf administrasi yang dapat dijadikan sebagai model (contoh) bagi peserta didik.

2. Kegiatan spontan, misalnya saja ada perilaku negatif dari peserta didik maka guru perlu memberikan dan memberitahu bagaimana sikap dan prilaku yang baik. Kegiatan spontan tidak hanya berkaitan dengan prilaku negatif, tetapi jika ada kegiatan positif juga perlu ditanggapi oleh guru.

3. Teguran, guru perlu menegur peserta didik yang melakukan perilaku buruk dan menanamkan nilai-nilai kebaikan

4. Pengkodisian lingkungan, dengan cara mengkodisikan lingkungan sekolah sedemikian rupa. Misalnya menyediakan tempat sampah, jam dinding, sloganslogan mengenai budi pekerti dan tata tertib sekolah yang dapat dibaca peserta didik dengan mudah

5. Kegiatan rutin, misalnya kegiatan baris di depan ruangan sebelum masuk kelas, berdoa sebelum dan sesudah kegiatan, mengucap salam, membersihkan kelas serta belajar dengan rajin. ${ }^{16}$

${ }^{16}$ Zuriah, N. Pendidikan Moral \& Budi Pekerti Dalam Perspektif Perubahan. Jakarta: Bumi Aksara, 2015), 247. 


\section{KESIMPULAN}

Gerakan literasi sekolah di SMK Nusantara sudah pada tahap pembelajaran, yakni pelaksanaan berbagai strategi untuk memahami teks dalam semua mata pelajaran, yang kemudian didukung dengan penggunaan lingkungan fisik, sosial afektif dan akademik disertai beragam bacaan (cetak, visual, auditori, digital), yang kaya literasi di luar buku teks pelajaran untuk memperkaya pengetahuan dalam mata pelajaran. Budi pekerti siswa kelas x di SMK Nusantara ditingkatkan dengan mengamalkan akhlak terhadap Tuhan, terhadap sesama juga terhadap lingkungan. Implementasi gerakan literasi sekolah dalam meningkatkan budi pekerti siswa kelas x di SMK Nusantara dengan: keteladanan atau contoh yang dilakukan oleh guru, kegiatan spontan, teguran atau hukuman yang diberikan pada siswa yang tidak mengikuti kegiatan literasi, pengkodisian lingkungan dengan penyediaan lingkungan yang literat dan kegiatan rutin

\section{DAFTAR PUSTAKA}

- Adisusilo, S, Pembelajaran Nilai Karakter Kontruktivisme dan VCT Sebagai Inovasi Pembelajaran Aktif. Jakarta: Raja Grafino Persada : 2013.

Ainamulyana. bttps:/ / ainamulyana.blogspot,com/2018/06/undang-undang-uu-nomor-20tabun-2003.btml?m1. (2018)

D. P. Kemendikbud, Materi Pelatihan: strategi Literasi Dalam Pembelajaran, 2017.

H. Yunansah, \& T., Mulyani, Y., Abidin, Pembelajaan Literasi Strategi Meningkatkan Kemampuan Literasi Matematika, Sains, Membaca, dan Menulis. . (Jakarta: Bumi Aksara, 2018.

N. Zuriah, Pendidikan Moral \& Budi Pekerti Dalam Perspektif Perubahan, Jakarta: Bumi Aksara : 2015. 